Gasimova N.A., Edilov E. Z.•

DOI: 10.25108/2304-1730-1749.iolr.2018.54.54-74

\title{
Psychological aspects of motives of terrorist activity
}

Abstract: Generally, it should be noted that the motifs vary widely, depending on the specific type of terrorist activity, and even the motives of its different participants within the same terrorist act may be different.

An unusual psychological situation arises during the terrorist act, when people act in a way that is completely different from ordinary life-forms.

Consequently, it should be noted that when talking about terrorism that causes many victims of human beings, one of the main motives is the death and destructive tendency of certain people. It can not be otherwise, because the tendency to death is somewhat similar to interest and inclination, and there can be both of these trends in a particular human. A large group of people who are inclined to death unite people. They solve their problems by spreading death, using it, or approaching death as close as possible.

The issue of finding ways to prevent terrorism is in the center of attention of the international community, as well as separate subjects of terrorism, various scientific research centers. One of the ways to effectively combating terrorism, one of the global challenges of the modern era, is its scientifically-psychological aspect of research, the accessibility of materials to security and the application of law enforcement agencies.

\footnotetext{
"Gasimova Naila Azad qizi - Senior Research Fellow of "The legal provision of state security" Department of the Institute of Law and Human Rights of ANAS (Azerbaijan). E-mail: naila.qasimova1967@gmail.com

Edilov Elburus Zaitkhan oglu - Researcher of "The legal provision of state security" Department of the Institute of Law and Human Rights of ANAS (Azerbaijan). E-mail: edilov-elburus@mail.ru
} 
In view of the foregoing, we can see that the terrorist has never had a rational change of mind. They do not have the feeling of fear and regret for what they do and what they do. It is wrong to put the terrorist into a mental illness and it does not give any results. The illiterate and primitive human imagination about the terrorist is wrong.Therefore, the study of the psychological aspects of the motives of terrorist activity is an important issue and should always be in the center of attention.

Keywords: terrorism activities; formation of motives of terrorist activity; psychology aspect of the behavior of terrorists; factors that combine the behavior of terrorist groups

Qeyd etmək lazımdır ki, psixologiyanın bir çox sahələrinə dair respublika səviyyəsində xeyli araşdırmalar aparılmış, dərsliklər və dərs vəsaitləri yazılmışdır. Lakin terrorçuların davranışının psixoloji aspektləri sadalananlarla müqayisədə çox az tədqiq olunmuşdur.

Ümumiyyətlə, istər adi bir insan, istərsə də terrorçunun fəaliyyətini nəzərdən keçirdikdə onun özünəməxsus quruluşu diqqəti cəlb edir. İnsanın hər cür fəaliyyəti eyni quruluşda, eyni sistem və ardıcıllıqda həyata keçir. Başqa sözlə, bütün fəaliyyət növlərində eyni ümumi struktur komponentlər özünü göstərir. İnsanın istər maddi, istərsə də mənəvi fəaliyyətinin quruluşunu təhlil etdikdə onun təxmini məzmununu təşkil edən aşagıdakı əsas elementləri, komponentləri aşkara çıxarmaq mümkün olur: fəaliyyətin motivləri, fəaliyyətin məqsədi və fəaliyyətin vasitələri [1].

Motivlər insanı hər hansı bir fəaliyyətə təhrik edən, yönəldən səbəblərdir. Hər cür fəaliyyət zamanı müvafiq tələbatdan doğan səbəblər bizi həmin fəaliyyətə girişməyə və bu yolla öz tələbatımızı ödəməyə yönəldir. Məqsədə gəldikdə o, insanın fəaliyyət zamanı hansı nəticəyə nail olmağa yönəlməsidir. Son nəticə daima fəaliyyətin məqsədi kimi təzahür edir. Məhz buna görə də insan fəaliyyəti 
daima dərk olunmuş məqsədləri ilə tənzim edilir. İnsanın həmin fəaliyyəti nə dərəcədə adekvat yerinə yetirməsi qarşıya qoyulan məqsədi həyata keçirməsi ilə xarakterizə olunur. Fəaliyyətin vasitələrinə gəldikdə o, həmin fəaliyyətin həyata keçirildiyi yollardır. Başqa sözlə insan həmin fəaliyyət zamanı qarşısına qoyduğu məqsədə hans1 yollarla nail olmasidır [10].

Motivlər hər şeydən əvvəl bir-birlərindən tələbatların növlərinə görə fərqlənirlər. Bununla yanaşı olaraq motivlər tələbatların kəsb etdiyi formalara, onların genişliyinə və ya məhdudluğuna, reallaşdıqları fəaliyyətin konkret məzmununa və s. görə fərqlənirlər. Təcrübə göstərir ki, fəaliyyətin mərəkkəb növləri, adətən, bir motivə deyil, eyni vaxtda təsir göstərən bir neçə motivə cavab verir ki, bu da motivləşmə adlanır. Motivləşmə elə motivlər birliyidir ki, şəxsiyyətin yönəlişliyini müəyyən etməklə onun fəaliyyətinin səmərəliliyini də şərtləndirir.

Qeyd edilənlərlə yanaşı olaraq özünün xarakteri və fəaliyyət prosesində oynadığı rola görə motivlərin aşağıdakı növlərini qeyd etmək olar: 1) situativ və geniş motivlər; 2) fəaliyyətin nəticəsinə və onun özünə doğru yönələn motivlər; 3) eqoistik və ictimai əhəmiyyətli motivlər.

Ümumiyyətlə, motivləri təzahür xüsusiyyətlərinə görə psixoloji ədəbiyyatdageniş istifadə olunan iki qrupa ayırmaq mümkündür: 1) geniş sosial motivlər və 2) idrak motivləri [8].

Qeyd edilənlərdən aydın olur ki, terrorçular hər-hansı bir işi müvəffəqiyyətlə yerinə yetirməsi üçün iş və ya hərəkətləri idarə etmək və təshih etmək bacarığına malik olması zəruridir. İşləri təşkil edən hərəkətlər sistemi isə nəticə etibarilə həmin işlərin məqsədilə idarə və tənzim olunur. Yerinə yetirilən işlərin nəticələri həmin işin məqsədi nöqteyi-nəzərdən qiymətləndirilir və təshih olunur. Başqa sözlə, məhz işin məqsədi şeylərin hansı xassə və vəziyyətlərinin onun icrası, nəzarət və təshihi üçün oriyentir olmasını təyin edir. 
Psixoloqlar qeyd edirlər ki, 25-29 yaşlı şəxslər daha çox kriminogen fəallığa malik olur. Onların ardınca 18-24, 14-17, ən nəhayət 30-35 yaş11 şəxslər gəlir. Qətl, sağlamlığa xəsarət yetrimək, soyğunçuluq, oğurluq, xuliqanlıq 30 yaşına qədər şəxslər tərəfindən törədilir. Müəlliflərin çoxu bildirirlər ki, gənclərin kriminogen fəallığı onların aşağı emosional sabitliyi, yüksək impulsivliyi, aqressivliyi, sosializasiyanın lazmi səviyyədə olmaması, sabit həyat planlarının olmaması ilə bağlıdır. Cinayət törədənlərin ümumi təhsil səviyyəsi bir qayda olaraq aşağıdır. Zorakı və zorakı-tamahkar cinayətlər törədən şəxslərin təhsil səviyyəsi aşağıdır. Təhsil səviyyəsi nisbətən yüksək olan şəxslərin arasında az-çox vəzifə cinayətlərinin törədilməsi üstünlük təşkil edir [4].

Yuxarıda göstərilənləri nəzərə alaraq terror fəaliyyətinin motivlərini aşağıdakı qruplara bölə bilərik:

Birinci ideoloji motivlər. Bu daha dayanıqlı motivdir. Burada fərdin şəxsi dəyərləri ilə aid olduğu qruplaşmanın, terror təşkilatının mövqeyi və dəyərləri eynidir. Belə vəziyyətdə terror insan üçün sadəcə şəxsi ideyalarını həyata keçirmək yolu deyil, eyni zamanda qruplaşma tərəfindən verilən vacib "tapşırıq", "missiya" olur.

İkinci motiv - dünyanı dəyişmək istəyidir. Dünyada mövcud ədalətsizliyi və natamamlığ1 anlayaraq onu dəyişmək üçün israr etməkdir.

Üçüncü motiv - insanlar üzərində hakim, güc, ixtiyar sahibi olmaq istəyidir. $\mathrm{Bu}$ ən qədim, dərin motivlərdən sayılır və daim öz mövqeyini saxlayır.

Dördüncü motiv - terror fəaliyyətin bir növü kimi diqqəti cəlb edir və maraq kəsb edir. Bəziləri, xüsusilə də maddi rifahı yaxşı olanlar və təhsilli insanlar üçün terror qeyri-adi fəaliyyət mühitidir.

Beşinci motiv - emosional bağlılıq, "yoldaşlıq" motivləri - terroraqədərki həyatında qohumlara, ailəyə, yaxınlara və s. dəymiş ziyana görə qisasdır.

Altıncı motiv - özünü reallaşdırma (özünü doğrultma). Bu inanılmaz, qeyriadi (paradoksal) motivdir.Bir tərəfdən özünü doğrultma güclülərə xas 
xüsusiyyətdir, digər tərəfdən - terror aktında özünü doğrultma - imkanların məhdud olduğunun qəbulu və dünyaya təsirin başqa yolunu tapa bilməyən insanın uğursuzluğunun etirafıdır [2].

İlk öncə qeyd etmək lazımdır ki, siyasi, milli və "ideoloji” terrorçuların hər bir hərəkəti rasional, əvvəlcədən düşünülmüş və hazırlaşmış olur. Məhz buna görə də onların tapılıb saxlanılması çox çətin problemə çevrilir. Eyni zamanda terrorçuların ağıllı, öz məqsədlərini bilən və açıq motivlərlə hərəkət edən insanlar olduqları şübhəsizdir. Lakin işıqlı ideyaları və qeyri-insani amansızlığı, əqidə yüksəkliyini və baxışların, biliklərinin primitivliyini, digərləri uğrunda candan keçməyə hazır olmağı və öz niyyətləri naminə minlərlə insanların məhv edilməsinin mümkünlüyünə inamını bir arada cəmləmək, birləşdirmək mümkün deyil. Məhz, buna görə də terror aktlarının motivlərinin aydınlığı və açıqlığ kifayət qədər qaranlıqdır. İnsanın bir çox digər əməlləri kimi terrorçuluğun motivasiyası da qəliz, çox səciyyəvi və çox tərəfli xarakter daşıyır. Onları birbirindən yalnız mənsub olduğu konkret cinayət aktının növündən asılı olaraq, fərqləndirmək lazımdır.

Terror fəaliyyətinin motivləri sırasında özünütəsdiq motivi əsas yerlərdən birini tutur. Özünü təsdiq motivinin əsasında ətrafdakıları ram etmək və onları idarə etmək istəyi dayanır, bu isə öz növbəsində dominantlıq etmək istəyinə bağlıdır. Bu cür tələbat isə öz növbəsində sosial mühitdə zorakılıq, güc tətbiq etmə və narazı olanları məhv etməklə əldə edilən hökmranlıqdan yaranan yüksək narahatçılıqla bağlıdır. Qeyd olunan motiv terror fəaliyyətinin istənilən tipində müşahidə olunur, belə ki, digərlərini ram etmə şəxsi təhlükəsizliyin təmin olunmasının da əsasında dayanır. Bütün ətrafı qorxu içində saxlayan meşə quldurları və onların başçısı, dəstə komandiri əhalini daim qorxutduğu və zor tətbiq etdiyi zamanda özünü nisbətən təhlükəsiz hiss edəcək. Məhz terror aktı zamanı cinayətkar nəyə qadir olduğunu və nəyi göstərmək istədiyini nümayiş etdirir (ağıl, qorxmazlıq, çeviklik və cəldlik, texniki bacarıq və s.) və bununla da 
özünü təsdiq edir, yəni bu keyfiyyətlərin onda olduğunu ilk növbədə özünə sübut etməyə çalışır [6]. Hər hansı terror aktı məhz bu məqsədlə də törədilə bilər.

Bəzi terrorçular, xüsusilə də sui-qəsd edən terrorçular, ölümə vurğun olsalar da, eyni zamanda sui-qəsdi seçərək özlərini ölümsüzləşdirməyə cəhd edirlər və bununla da ölüm qarşısındakı qorxularını yox etməyə çalışırlar. Məsələ bundadır ki, ölümü intişar etmək və ya yaymaq ölüm qarşısındakı qorxunu yox etməyin yeganə yoludur. Belə ki, ölüm insana yalnız bu zaman maksimum yaxınlaşır və daha aydın olur. Sui-qəsd edən terrorçu yüksək narahatlıq hissi olan şəxsdir və məhz buna görə də şüuraltı səviyyədə ona narahatç1lıq gətirən səbəbi axtarır. $\mathrm{Bu}$ səbəb isə ölümdür. Heç də təsadüfi hal deyil ki, terror aktı həyata keçirdiyi zaman sağ qalan terrorçular təkrar ölümə can atırlar [9].

Terror təşkilatları və terrorçular haqqında danışarkən nəzərə almaq lazımdır ki, tək terrorçulara nisbətən az rast gəlinir. Oksər hallarda terrorçular liderin güclü təsiri olan qruplarda birləşirlər. Bunu "AUM Sinrikyö” kimi terrorda iştirak edən dini qruplaşmalarda və sektalarda müşahidə etmək olar. Bu, dövlət terroru olduqda, onun lideri (rəhbəri) qeyri-məhdud hakimiyyətə malik olur və o, bütövlükdə dövlət terrorunu hazırlayaraq istiqamətləndirir. Qruplaşmanın bütün fəaliyyəti, hətta, nəhəng sosial-psixoloji münasibətlər, daxili iyerarxiya onun ixtiyarında olur. Onun hakimiyyəti hüdudsuz olur və hər kəs ondan möcüzə gözləyir. Eyni zamanda o, özünün möcüzə yarada biləcəyinə inanır. Belə bütə sitayiş sərhəd tanımır. Belə hal Hitler və Stalinin hakimiyyəti dövründə müşahidə olunub [3].

Terror qruplaşmalarının məxfiliyinin qorunması, mühitin daimi düşmənçiliyi onun üzvlərinin ciddi nizam- intizamını, rolların sərt və dəqiq bölünməsini, ümumi qərarlara və əmrlərə şərhsiz tabe olmağı müəyyənləşdirir. Bu cür qruplaşmalarda üzvlər arasındakı psixoloji əlaqə olduqca möhkəmdir. Bu isə öz növbəsində motivlərə və motivasiya prosesinə təsir göstərir. Məsələn, bu, özünü qrup üzvlərinə tabe olmaq və qrup qarşısında özünü doğrultmaq istəyində, yəni sosial-psixoloji səviyyədə büruzə verir. 
Motivlərin formalaşması və həyata keçirilməsinə təsir edən terrorçuluğun psixoloji xarakteristikası deyilənlərlə kifayətlənmir. Ümumi insan dəyərlərindən imtina etmək, aqressiya və qəddarlığın yüksək səviyyədə olması, hər bir zaman haqlı olduqlarına inam və qurbanlarına rəhm hissinin olmaması (yoxluğu) zorakılığa meylli digər təhlükəli cinayətkarlarda olduğu kimi terrorçulara da xasdır. Terrorçuların təsəvvüründə qurbanlar, əsasən də çox olduqları halda konkret insan simasında olmayıb, cizgisiz insan kütləsini xatırladırlar. Bundan əlavə terrorçular nümayişə can atır, hər hansı bir terror aktını həyata keçirdikdən sonra kütləvi informasiya vasitələri ilə bu zorakılığın məhz onlar tərəfindən törədildiyini ictimaiyyətə bildirmək istəyirlər. $\mathrm{Bu}$ da birbaşa olaraq terrorçuluğun vacib elementlərindən sayılan qorxu yaratmaq istəyi ilə əlaqəlidir. Adı çəkilən meylin olması, həmçinin onu əks etdirir ki, terrorçular, o cümlədən də terrorçuicraçılar arasında psixi normalar çərçivəsindən kənara çıxan, əsəbi (isterik) şəxslər çoxdur.Bəzi terrorçuların aqressiv, zorakı fəaliyyəti heç də dağıdıcı meyillərdən irəli gəlmir, sadəcə onlar verilmiş tapşırığa uyğun, məhz bu cür davranmağı özlərinə borc bilirlər [5].

Beləliklə, terrorçuluğun psixoloji kökləri insan tarixinin dərinliklərində gizlənir, Ana və Ata arxetipləri ilə əlaqəlidir. Terror qruplaşması mürəkkəb strukturu və qrup dinamikasının xüsusiyyətləri ilə seçilir, bəzi terrorçular aqressivlik, qəddarlıq, fanatik əminlik, insanlardan psixoloji uzaqlaşma, konformizm və narsisizm kimi bir çox xüsusiyyətlərə malikdirlər. Onların içərisində nekrofil şəxsiyyətlər də az deyil [2].

Lakin onu da qeyd etmək lazımdır ki, bəzi terrorçuları özləri də dövlətdən nə tələb etdiklərini tam anlamırdılar. Onlar bu yolla nifrət etdikləri hakimiyyətə qarşı mübarizə aparırdılar, eyni zamanda, bütün uğursuzluqlarında dövləti günahkar bilirdilər və bu yolla ətraf aləmə olan şüuraltı nifrəti nümayiş etdirirdilər. Doğru və ya yalan incikliyə, şəxsi məğlubiyyətə və puç olan arzulara görə qisas alırdılar. Tterror yolu ilə müharibə həmişə geniş yayılmış olub. Oksər hallarda bu 
(terrorçuların təmsil etdikləri) şəxslərin dövlət orqanları ilə mübarizəyə gücü çatmadıqda terror aktları daha da aktuallaşır.

Xarici və yerli mütəxəssislər tərəfindən çoxsaylı təhqiqatların aparılmasına baxmayaraq, terrorçular xüsusi diaqnostik-psixiatrik kateqoriyaya daxil edilmirlər. Müqayisəli təhqiqatların bir çoxu bütün terrorlarda heç bir ruhi anormallıq əlamətlərinin aşkar olunmadığını göstərir. Buna baxmayaraq, mütəxəssislər terrorçuların bu sahəyə şəxsi meyilliyi olduğundan üz tutduqlarını sübut etməyə çalışırlar.

Terrorçu qrupların müxtəlif olduğuna baxmayaraq, onların hamısını birləşdirən bir amil var. $\mathrm{Bu}$ da hər bir üzvün öz təşkilatının vəzifələrinə və ideyalarına kor-koranə sadiq olmasıdır. Belə düşünmək olar ki, insanların bu cür təşkilatlara daxil olmaları, məhz həmin məqsədlər və ideyalarla bağlı olmaları ilə izah olunur. Lakin bu heç də mütləq şərt deyil. Osl səbəb bu insanların hər hansı bir qrupa daxil olmaq istəyi və özlərini təsdiq etmək tələbindən irəli gəlir. Adətən, terrorçu qrupların üzvləri uğursuz ailələrdən çıxan, ictimai strukturlar çərçivəsində müəyyən çətinliklərlə üzləşən və iş yerlərini itirən, yaxud da heç vaxt işləməyən insanlar olur. Bu insanlar özlərini cəmiyyətdən təcrid olunmuş hiss edirlər və bu hiss onları belə antisosial təşkilatlara daxil olmağa vadar edir. Beləliklə, terrorçuların ümumi cəhəti onların bu cür özləri kimi insanların aid olduğu qruplara can atmasidir.

Oksər hallarda terrorçular ənənəvi dindar mühitdə tərbiyə almış gənclərdir. $\mathrm{Bu}$ insanlar öz millətinə bağlı olurlar və beyinlərində onların millətinə pislik etmiş “tarixi düşmən” haqda şişirdilmiş təsəvvürlər yaranır. Buna görə onlar daima qisas almaq hissi ilə yaşayırlar. Ailə üzvlərinin, yaxınlarının, yaxud da həmvətənlərinin, hətta gözləri qarşısında öldürülməsi, onlarda bu hissi daha da möhkəmləndirir.

Terrorçunun davranışı adətən, antisosial davranışın parlaq və tam aşkar növünü nümayiş etdirir. Ümumi qiymətləndirməyə görə belə davranış anormal olub, özündə patoloji komponenti cəmləşdirir. Terrorçu anormal şəxs deyil, sadəcə 
olaraq bəzi xüsusiyyətləri qabarıq nəzərə çarpan şəxsdir. $\mathrm{Bu}$ o deməkdir ki, terrorçu ümumiyyətlə normal insandır, lakin şəxsiyyətinin bəzi xüsusiyyətləri özünü daha güclü büruzə verir. Terrorçunun psixikasının patoloji komponenti xasiyyətin bəzi xüsusiyyətlərini büruzə verməkdən başlayaraq psixopatiyaya qədər dəyişə bilir. Birinci halda xüsusiyyətlər kompensasiya olunur və yalnız müəyyən hallarda (vəziyyətlərdə) özünü büruzə verir. Ona görə tutulduqdan sonra aparılan müayinə zamanı bu xüsusiyyətlər aşkarlanmaya bilər [7].

Birinci haldan fərqli olaraq ağır psixopatiya terror aktı həyata keçirilmədikdə də açıq şəkildə müşahidə olunur. Kompensasiya mexanizmləri zəif olur, psixopatik xüsusiyyətlərin yalnız bir hissəsi əhatə olunur. Dekompensasiya nəzərə çarpmayan səbəblərdən və hətta səbəbsiz yaranır, pozğunluğun son həddində cinayətlər və hətta sui-qəsd törədilə bilər. Adətən, daimi və mühüm sosial dezadaptasiya müşahidə olunur. Terrorçunun keçmişinə nəzər salsaq, onun erkən yaşlarından valideyn himayəsindən və qayğısından məhrum olduğunu, çətin yeniyetməlik, alçalma, itki (ev, yaxınlar, maddi və sosial status və s.) və çatışmazlıqlar içində keçirilmiş gəncliyi görmək olar.

Terrorçuların sıralarını artıran əsas göstəricilərdən biri də həmçinin sosiumların mədəniyyətində onların ölümü, qəhrəmanlıq və ilahi qurbanlarin olmasıdır. Bu cür qurban həmişə bəyənilir, dəstəklənir və terrorçunun bütün ailə üzvlərinə və nəslinə böyük hörmət və qayğını təmin edir. Bu o demək deyil ki, ailəiər terrorçuları dəstəkləyir və ağır kədər hissi keçirmir, sadəcə olaraq həm terrorçular, həm də onların ailə üzvləri dərd və itki ağrısı ilə, eyni zamanda qurbanın qəbul edilməsini, anlayış, dəstək və hətta qürur hissi keçirəcəklərini bilirlər. Bu cür ölüm sui-qəsd deyil, konkret şəxsin cəmiyyətin və ya millətin keçmişinə, bu gününə və gələcəyinə tarixi iz qoymaqdır.

Amma əksər hallarda terrorçunu bu və ya digər problemlər narahat etmir və hissiyyatsız maşın kimi hərəkət edirlər. Psixoloji analiz nəticəsində üç bu cür "terror maşmı"m ayırmaq olar. Birinci variant "zombi sindromu" adlanır. Zombi 
sindromu hər zaman döyüşə hazırlıq vəziyyətidir. Bu özünə görə özünü təsdiq etməyə və hər zaman hazırlıqlı vəziyyətdə olduğunu göstərməyə çalışan "döyüşçü sindromudur". Bu sindrom icraçı terrorçulara və aşağı səviyyəli döyüşçülərə aid olunur. İkinci variant "Rembo sindromudur". Bu sindromun psixoloji əsas1 “missionerlikdir”. "Rembo" heç kimi elə-belə öldürmür. $\mathrm{O}$, bunu mütləq yüksək ideya naminə etməlidir. Buna görə, o, həmişə çətin və riskli "missiyalar axtarışındadır". Üçüncü variant "Kamikadze sindromudur". Bu sindromun əsas psixoloji xüsusiyyəti ondadır ki, bu cür terrorçular öz ideyaları naminə həyatlarını qurban verməyə həmişə hazırdırlar [2].

\section{References}

1. Bayramov A., Aliyev B. Huquq psixologiyasi [Legal psychology], Baku, Tehsil, 2012, $656 \mathrm{p}$.

2. Ceferov Arif. Terrorcularin psixologiyasi [Psychology of terrorists], Manual. Baku, 2018, 120 p.

3. Usubov Mutellim. Terrorçulugun kriminoloji xarakteristik xususiyyetleri [Particularities of criminology characteristics of terrorism], Baku, UniPrint, 2008.

4. Abramova G.S. Vvedenie v prakticheskuyu psikhologiyu [Introduction in practical psychology]. Moscow, 1994, 368 p.

5. Lukabo P., Fukua E., Kengemi G. Terrorizm - psikhologicheskie i politicheskie aspekty [Terrorism: psychological and political aspects]. Inostrannaya psikhologiya [Foreign psychology]. No. 10, 1998.

6. Malkina-Pykh I.G. Ekstremal'nye situatsii: Spravochnik prakticheskogo psikhologa [Extreme situations: Guidelines of practical psychologist]. Moscow, 2005, 960 p.

7. Mendelevich V.D., Sadykova R.G. Psikhologiya zavisimoyi lichnosti [Psychology of dependent personality]. Kazan, 2002, 240 p. 
8. Psikhologi o terrorizme (materialy kruglogo stola) [Psychologists about terrorism (materials of round table)]. Psychological journal. No. 4, 1995.

9. Reshetnikov M.M. Psikhologicheskyi portret terrorista [Psychological portrait of terrorist]. Doklad na forume "Psikhologiya i psikhopatologiya. Gumanitarnye strategii antiterrora" [Report on forum "Psychology and psychopathology of terrorism. Humanitarian strategies of antiterrorism"]. S. Peterburg, 23-25 May, 2004.

10. http://elnurrustamov.az/index.php/az/home/article/340 